Review

\title{
Micronutrients in Sepsis and COVID-19: A Narrative Review on What We Have Learned and What We Want to Know in Future Trials
}

\author{
Matteo Rossetti $^{1}(\mathbb{D})$, Gennaro Martucci ${ }^{1}(\mathbb{D})$, Christina Starchl ${ }^{2}\left(\mathbb{D}\right.$ and Karin Amrein ${ }^{2, *}$ \\ 1 Department of Anesthesia and Intensive Care, IRCCS-ISMETT (Istituto Mediterraneo per i Trapianti e Terapie \\ ad Alta Specializzazione), 90133 Palermo, Italy; mrossetti@ismett.edu (M.R.); gmartucci@ismett.edu (G.M.) \\ 2 Division of Endocrinology and Diabetology, Department of Internal Medicine, Medical University of Graz, \\ Auenbrugger Platz 15, 8036 Graz, Austria; christina.starchl@stud.medunigraz.at \\ * Correspondence: karin.amrein@medunigraz.at; Tel.: +43-316-3858-2383; Fax: +43-316-3851-3428
}

check for

updates

Citation: Rossetti, M.; Martucci, G.; Starchl, C.; Amrein, K. Micronutrients in Sepsis and COVID-19: A Narrative Review on What We Have Learned and What We Want to Know in Future Trials. Medicina 2021, 57, 419. https://doi.org/10.3390/ medicina57050419

Academic Editors: Antonio Mirijello and Alberto Tosoni

Received: 27 March 2021

Accepted: 21 April 2021

Published: 26 April 2021

Publisher's Note: MDPI stays neutral with regard to jurisdictional claims in published maps and institutional affiliations.

Copyright: (c) 2021 by the authors. Licensee MDPI, Basel, Switzerland. This article is an open access article distributed under the terms and conditions of the Creative Commons Attribution (CC BY) license (https:// creativecommons.org/licenses/by/ $4.0 /)$.

\begin{abstract}
Sepsis remains the leading cause of mortality in hospitalized patients, contributing to 1 in every 2-3 deaths. From a pathophysiological view, in the recent definition, sepsis has been defined as the result of a complex interaction between host response and the infecting organism, resulting in life-threatening organ dysfunction, depending on microcirculatory derangement, cellular hypoxia/dysoxia driven by hypotension and, potentially, death. The high energy expenditure driven by a high metabolic state induced by the host response may rapidly lead to micronutrient depletion. This deficiency can result in alterations in normal energy homeostasis, free radical damage, and immune system derangement. In critically ill patients, micronutrients are still relegated to an ancillary role in the whole treatment, and always put in a second-line place or, frequently, neglected. Only some micronutrients have attracted the attention of a wider audience, and some trials, even large ones, have tested their use, with controversial results. The present review will address this topic, including the recent advancement in the study of vitamin $\mathrm{D}$ and protocols based on vitamin $\mathrm{C}$ and other micronutrients, to explore an update in the setting of sepsis, gain some new insights applicable to COVID-19 patients, and to contribute to a pathophysiological definition of the potential role of micronutrients that will be helpful in future dedicated trials.
\end{abstract}

Keywords: vitamin D; vitamin C; zinc; thiamine; nutrition; critically ill patients; infections; mitochondria; shock

\section{Introduction}

In the USA alone, apart from COVID-19, sepsis affects around 1.5 million people annually [1]. Based on the most recent epidemiological trends, incidence of sepsis is growing [2], with an incidence that is more than 5-fold greater in the elderly population [3]. In a trend analysis conducted from 1993 to 2003, the percentage of severe sepsis cases requiring hospitalization increased from $25 \%$ to $44 \%$ [4]. In-hospital sepsis mortality has been estimated up to $140 \%$ higher compared to annual estimates of mortality due to other causes [5].

Sepsis remains the leading cause of mortality in hospitalized patients, contributing to 1 in every 2-3 deaths [6]. It is the result of a complex interaction between host response and the infecting organism, resulting in life-threatening organ dysfunction, depending on microcirculatory derangement, cellular hypoxia/dysoxia driven by hypotension and, potentially leading to death. All these processes are finely regulated by merging pathways involving a number of cells and mediators.

Standard care for septic patients still involves the first-hour bundle, with the explicit intention of beginning resuscitation and management immediately. Mainstays of treatment are still lactate monitoring, early diagnosis/treatment using cultures and broad-spectrum 
antibiotics, as well as adequate hemodynamic support to guarantee adequate end-organ perfusion [7]. However, the high energy expenditure driven by a high metabolic state induced by the host response can rapidly lead to micronutrient depletion [8]. This deficiency can result in alterations in normal energy homeostasis, free radical damage, and immune system derangement [6]. In the critically ill septic patient, the adjunctive administration of vitamins and micronutrients, especially in defective scenarios, could lead to a better energy expenditure homeostasis [9]. Moreover, vitamins, and generally micronutrients, despite being neglected for years in the critically ill population, may represent a missing tool in the regulation of processes involved in sepsis, due to their ubiquitous presence and action, the involvement in several biochemical reactions as a cofactor and, in some cases, with indirect genomic and non-genomic effects on the cells involved in the inflammation pathways.

This review will address the topic, including the recent advancement in the study of some micronutrients, including vitamin $\mathrm{D}$, vitamin $\mathrm{C}$, thiamine, and zinc. These are the micronutrients for which, despite controversies, there is some evidence and associations between the disease severity in critically ill patients and their deficiency. In other cases, they have been tested as supplementation in clinical studies.

The field of micronutrients has been entered into clinical studies recently and suffers from methodology biases in clinical studies, since the exploration of such a topic was mainly relegated to pre-clinical interest. However, with its potential for fine-tuning the regulation of biochemical processes and the high evidence of association between disease severity and their deficiency, it is worthy of consideration by clinicians.

In this light, we will give an overview of the actions of micronutrients and their involvement in sepsis and in COVID-19, which has several clinical features in common with severe sepsis.

\section{Vitamin D}

Initially discovered and studied as a major regulator of calcium metabolism, vitamin D also plays an essential role as an immunomodulatory hormone [10] and in several biological activities interfering with the innate and adaptive immune system, with a role even in liver transplant recipients regarding graft function and sepsis incidence [11]. This is also proven by the fact that vitamin D receptors are expressed by immune cells such as lymphocytes, monocytes, macrophages, and dendritic cells [12].

\subsection{Physiology and Requirements}

There are two forms of native vitamin D. Vitamin $\mathrm{D}_{2}$ is synthesized from ergosterol and can be found in yeast and sun-dried mushrooms. Vitamin $\mathrm{D}_{3}$ is synthesized endogenously from 7-dehydrocholesterol in sun-exposed skin. Both $\mathrm{D}_{2}$ and $\mathrm{D}_{3}$ are metabolized by CYP2R1 (vitamin D-25 hydroxylase) [12] in the liver to 25-hydroxyvitaminD [25(OH)D], which is further metabolized by CYP27B1 to the active form 1,25-dihydroxyvitaminD $\left[1,25(\mathrm{OH})_{2} \mathrm{D}\right][12]$, which exerts its endocrine and immune effects by binding to the vitamin $\mathrm{D}$ receptor (VDR) in the nucleus [13]. 1,25OHD is usually only needed in advanced renal dysfunction and rare conditions, including hypoparathyroidism.

The main site of conversion of $25(\mathrm{OH}) \mathrm{D}$ is the kidneys. Evidence shows that circulating levels of $25(\mathrm{OH}) \mathrm{D}$ maintained in the range of $40-60 \mathrm{ng} / \mathrm{mL}$ are associated with the lowest risk of several types of cancer, and cardiovascular and autoimmune diseases [14]. In order to maintain the blood levels in the range of $20-40 \mathrm{ng} / \mathrm{mL}$, with minimal sun exposure, an adult would require the ingestion of 4000-6000 IU daily [15]; however, daily intakes using standard enteral/parenteral nutrition formulas rarely exceed $500 \mathrm{IU}$ daily.

\subsection{Vitamin $D$ and Immunity}

Vitamin D has a plausible link with response to infection. Macrophages and monocytes express CYP27B1 as a response to cytokines and IFN- $\gamma$. This enzyme converts $25(\mathrm{OH}) \mathrm{D}$ in the active form 1,25(OH)2D25, which is able to enhance macrophage and monocyte activity by the stimulation of the production of cathelicidin (LL-37), which acts by destabilizing 
microbial membranes [16]. Furthermore, it exerts antiviral effects by disrupting viral envelopes and altering the viability of host target cells.

In a mouse model, Horiuchi et al. found a low expression of the inflammatory molecule iTXB ${ }_{2}$ in mice receiving oral $1,25(\mathrm{OH})_{2} \mathrm{D}$ and intraperitoneal LPS compared to controls who were not receiving the vitamin D metabolite. A significant reduction in mortality was noticed [17].

As known, this modulation process is widely seen in clinical scenarios such as sarcoidosis and tuberculosis, explaining why, for example, some patients affected with granulomatous disorders develop hypercalcemia and hypercalciuria [18]. The upregulation of CYP27B1 also plays a role in regulating lymphocyte activity (reduces Th1 and Th17 activity and stimulates Th2 and Treg). Moreover, $1,25(\mathrm{OH})_{2} \mathrm{D}$ modulates tolerance in antigen-presenting cells (APC) by decreasing the expression of major histocompatibility complex class II (MHC-II) [19]. This leads to a decrease in IL-12 production and an increase in IL-10, with tolerogenic effects [20].

Even endothelial function is influenced by vitamin D. Several experimental studies have shown that it can modulate vascular permeability via multiple genomic and extra-genomic pathways. For example, $1,25(\mathrm{OH})_{2} \mathrm{D}$ is a transcriptional factor for endothelial nitric oxide synthase (eNOS), able to cause an upregulation of the gene expression augmenting nitric oxide production [21].

This is a potential role that may be interesting for the prevention and treatment of patients with severe cases of COVID-19, given that microangiopathy, coagulopathy, and thrombosis are frequent in COVID-19, and vitamin D deficiency is associated with a prothrombophilic profile, potentially reversible with vitamin D supplementation [22] In fact, high dose vitamin $\mathrm{D}$ supplementation has been associated with reduced in vitro thrombin generation and decreased clot density.

These effects use non-genomic pathways including adenylyl cyclase/cyclic adenosine monophosphate (AC/cAMP) and inositol triphosphate/diacilglycerole ( $\left.\mathrm{IP}_{3} / \mathrm{DAG}\right)$, which lead to an augmentation of intracellular calcium concentration [23].

Multiple studies have reported vitamin D effects also on gut integrity and intestinal homeostasis, showing an ability to alleviate intestinal damage from bacterial lipopolysaccaride [24]. Moreover, vitamin D can increase the expression of epithelial membrane junction proteins, crucial when facing bacterial translocation events.

Vitamin D's role in modulating adaptive immunity was originally observed on clonal human T-cell-expressing VDR [25]. It seems that resting T cells do not express VDR, while peripheral $\mathrm{T}$ cells do, making them a target of $1,25(\mathrm{OH})_{2} \mathrm{D}$ produced by macrophages and monocytes involved in the inflammatory response [25]. Vitamin D promotes a shift from Th1 and Th17 to Th2 and Treg immunity by enhancing Th2 cytokine expression while inhibiting Th1. This leads to the suppression of an uncontested proinflammatory state [25,26], even playing a potential role in protection from autoimmune diseases. This role in modulating inflammation is also evident in vitamin-D-deficient individuals, where CD4/CD8 ratios decrease as an indicator of immune activation [27], while the administration of $5000-10,000$ IUs of $\mathrm{D}_{3}$ can increase CD4/CD8 ratio [28,29].

\subsection{Vitamin D in the Critically Ill: The Septic Patient}

In a large study involving more than 3000 critically ill patients, vitamin D deficiency was a significant predictor of sepsis and carried a 1.6-fold increase in mortality [30]. Several observational studies have reported a connection between low levels of $25(\mathrm{OH}) \mathrm{D}$ and the incidence of sepsis; data also support the link between low serum vitamin D levels and the increase in morbidity and mortality in septic, critically ill patients. The reasons seem to be related to the effects of $1,25(\mathrm{OH}) 2 \mathrm{D}$ on the expression of pro-inflammatory cytokines of $\mathrm{T}_{\mathrm{H}} 1$ (IL-2, IFN- $\gamma, \mathrm{TNF}-\alpha$ ) and $\mathrm{T}_{\mathrm{H}} 17$ (IL-17, IL-12) [31-33].The role of vascular reactivity is under debate: lower levels of vitamin $\mathrm{D}_{3}$ are associated with worse outcomes, but vitamin D may, at the same time, exert non-genomic actions on endothelial cells to prevent extravascular leakage, and it may be reduced in its plasmatic levels by the vascular leakage 
itself due to systemic inflammation [34].Vitamin D's effects seem to encompass not only the modulation of the proinflammatory status, but also the local pathogen's control: Youssef and colleagues showed how the concentration of 50,000-90,000 IU/mL of $\mathrm{D}_{3}$ was able to inhibit the growth of or even kill strains of Staphylococcus aureus, Klebsiella pneumoniae, Escherichia coli, and Streptococcus pyogenes [35]. As a direct antimicrobial role becomes better understood, especially considering the modulating effect exerted by $1,25(\mathrm{OH})_{2} \mathrm{D}$ after LPS exposure, strong evidence connects vitamin D metabolites to a decrease in proinflammatory status, e.g., in yeast-induced sepsis [36]. In addition to basic biological research, some observational studies have explored vitamin D's role in the clinical setting. One observational study pointed to a connection between vitamin D plasma concentrations and respiratory infection [37], where Ginde et al. observed an inverse relationship between $25(\mathrm{OH}) \mathrm{D}$ levels and the incidence of upper respiratory infections (URI), data corroborated by Sabetta and colleagues' study, in which $25(\mathrm{OH}) \mathrm{D}$ levels greater than $38 \mathrm{ng} / \mathrm{mL}$ were associated with a 2-fold decrease in URI incidence [38]. In the critically ill population, several studies have revealed a high prevalence of poor vitamin D status [39]: in a singlecenter study, the prevalence of $25(\mathrm{OH}) \mathrm{D}<24 \mathrm{ng} / \mathrm{mL}$ was $79 \%$ [40], though lacking any association with mortality or hospital-acquired infections. In contrast, a retrospective study of 437 ICU patients showed a significant correlation between low vitamin D levels and $25(\mathrm{OH}) \mathrm{D}<20 \mathrm{ng} / \mathrm{mL}$ and mortality [41]. In a study of 70 patients divided into three groups, Jeng et al. found vitamin D insufficiency in 100\% of critically ill patients admitted with sepsis in the ICU (group 1) and in $92 \%$ when considering the non-septic ICU group (group 2), compared with $66.5 \%$ in the control group of normal healthy individuals (group 3) [42]. In a case-control cohort study of 36 ventilated patients admitted to the ICU, the group receiving a high-dose intramuscular injection of vitamin D obtained a significant reduction of ventilation days and length of stay.

A summary of the potential positive effects of vitamin D in sepsis is presented in Figure 1.

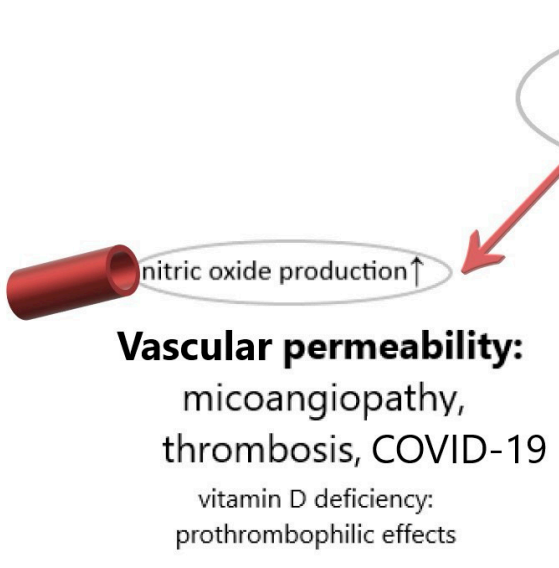

Gut integrity/intestinal homeostasis:

alleviates intestinal damage from baterial lipopolysaccharide, increases expression of epithelial membrane

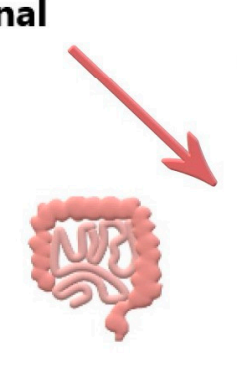

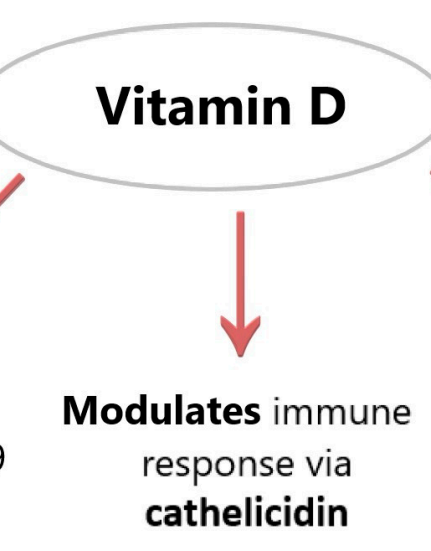

and APC

(decreasing

$\mathrm{MHC} I \mathrm{I})$

$\rightarrow$ tolerogenic effects

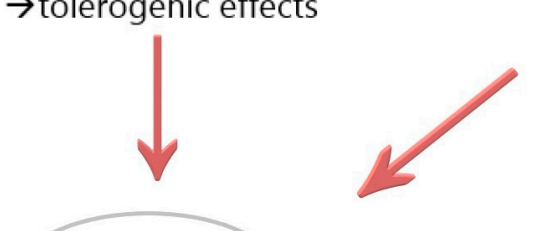

Sepsis
Vitamin D receptors

expressed by immune cells

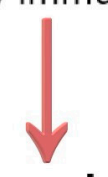

Immunomodulation:

anti-inflammatory anti-bacterial

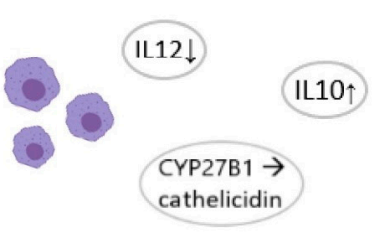

Figure 1. Summary of potential implications of vitamin D during sepsis. (APC: antigen-presenting cell; MCH II: major histocompatibility complex, class II; IL-12: interleukin 12; IL-10: interleukin 10). 


\section{Vitamin C}

\subsection{Physiology and Requirements}

Involved in several biosynthetic and metabolic processes, vitamin $C$ is essential for collagen and carnitine [43], and neurotransmitter synthesis [44] plays an antioxidant role [45], acting as an immunomodulatory agent [46] (Figure 2). The level considered normal in plasma [47], about $50 \mu \mathrm{mol} / \mathrm{L}$, according to the EU food safety authority, can be achieved by an intake of $90 \mathrm{mg} /$ day for men and $80 \mathrm{mg} /$ day for women. This is the plausible solution, at a population level, to avoid scurvy, but it has been not demonstrated that it is a sufficient intake in case of viral infections of other processes with a high level of antioxidant consumptions. The overt vitamin $C$ deficiency can be diagnosed by a plasma level below $11 \mu \mathrm{mol} / \mathrm{L}$, but it is rarely checked in hospitalized patients, and even among the most severe patients, this feature is definitely neglected [47]. This happens despite the fact that we know that the level of vitamins decreases rapidly in sepsis, trauma, surgery, and, recently, in COVID-19 patients.

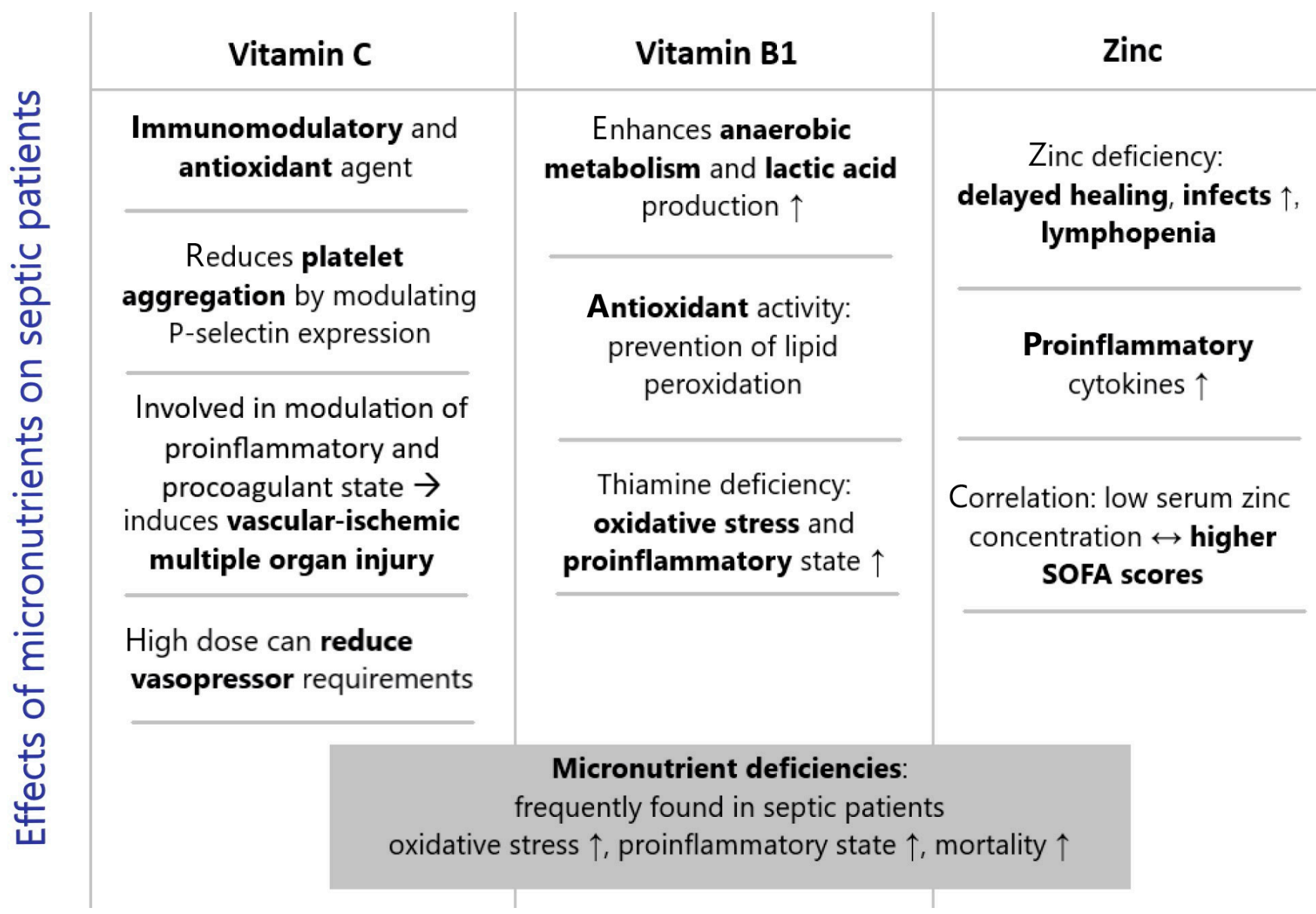

Figure 2. Effects of micronutrients on septic patients, other than vitamin D.

In septic patients, vitamin $C$ is involved in the modulation of the proinflammatory and procoagulant state believed to induce vascular-ischemic induced multiple organ injury [48]. In addition, vitamin $C$ seems to reduce platelet aggregation by modulating surface P-selectin expression [49], attenuate hypothalamic neuronal damage, and prevent immunosuppression, in addition to inducing endogenous vasopressor synthesis [50]. As with studies on vitamin $\mathrm{D}$, several studies have found a reduction in vitamin-C-circulating levels in septic patients admitted to the ICU, and deficiency may be exacerbated by the reduction in cell uptake due to inflammatory cascade activation (TNF- $\alpha$ and IL-1 $\beta$ can down-regulate the ascorbate-specific transporter [51]). On the other hand, plasma con- 
centration can lower ( $<10 \mathrm{micromol} / \mathrm{L})$ in the first $24 \mathrm{~h}$ after septic onset, an event that is strongly associated with an increase in the severity of organ dysfunction and mortality.

\subsection{Vitamin C in the Critically Ill Septic Patient}

Within the ICU population, to achieve normal plasma concentration and counteract organ dysfunction, high dose administration is necessary ( $3 \mathrm{~g} /$ daily) for $72 \mathrm{~h}$. This may reduce vasopressor requirements in septic shock and mortality in the ICU septic population [52], though more evidence will be needed. This hypothesis has a strong pathophysiological plausibility and relies mainly on a small and controversial before-after retrospective study [53]. Several RCTs were unable to demonstrate a reduction in mortality through the use of vitamin $C$, potentially due to several limitations, such as heterogeneous populations or too severe patients and a lack of early administration [54]. The principal criticism is the use of such a therapy in cases of advanced severe septic shock, at least in light of mortality as an outcome, since, as demonstrated for vitamin $\mathrm{D}$, the action of micronutrients on severely ill patients may be less relevant, likely because the severity of the organ failure is the result of several metabolic pathways that cannot easily be improved upon.

Another relevant topic on vitamin $C$ administration is related to the pharmacokinetic aspect. In fact, being a water-soluble vitamin, it is rapidly excreted if not used. For this reason, due to its rapid use in the oxidative process, the main results were reached with repeated administration every $6 \mathrm{~h}$. In the largest trial of intravenous vitamin $\mathrm{C}$ in sepsisassociated ARDS, the CITRIS-ALI trial [55], patients were given placebo or vitamin $C$ at a dose of $50 \mathrm{mg} / \mathrm{kg}$ every $6 \mathrm{~h}$ for 4 days. This means about an average dose of $3.5 \mathrm{~g}$ every $6 \mathrm{~h}$ in adults. Looking at the stated primary study outcomes, vitamin C did not improve markers of inflammation, vascular injury, or organ dysfunction. However, there were statistically significant benefits in three clinically relevant outcomes: mortality $(p=0.03)$, duration of ICU-free days ( $p=0.03)$, and hospital-free days $(p=0.04)$. As a matter of fact, examining the data, during the 4-day vitamin $C$ administration, mortality was $81 \%$ lower in the vitamin $C$ group, but after the cessation of study drug administration, there was no difference between the two trial groups. This study, as well as other similar negative studies, poses a relevant question about seeking proper evidence in critically ill patients, when the research objectives just apparently, contrast with the clinical effects.

\section{Other Micronutrients}

\subsection{Thiamine (Vitamin B1)}

Thiamine is a cofactor for several enzymes involved in aerobic carbohydrate metabolism, maintenance of cellular redox homeostasis, and synthesis of adenosine triphosphate [56] (Figure 2). In particular, thiamine is needed to convert pyruvate into acetyl-CoA, allowing entry into the citric acid cycle and aerobic metabolism. The human body has limited storage abilities within skeletal muscle, heart, kidney, and brain [57], and due to its quick turnover, without supplementation, deficiency can develop in just two weeks, with a clinical spectrum ranging from cardiac beriberi to Wernicke's encephalopathy [58].

In septic patients, thiamine deficiency is commonly found, with a prevalence of $20 \%$ to $71 \%$ : $20 \%$ of septic patients and $71 \%$ of those presenting with septic shock exhibit thiamine deficiency $(<9 \mathrm{nmol} / \mathrm{L})[59,60]$ (normal range of value is considered to be within 33-99 ng/mL). Several mechanisms have been identified to explain the association between thiamine deficiency and sepsis, though it remains unclear whether the deficiency can contribute as a cause of sepsis or if it is just a consequence. What is clear is that by decreasing pyruvate dehydrogenase activity (needed to convert pyruvate in acetyl-CoA to enter the citric acid cycle), thiamine deficiency can increase anaerobic metabolism and lactic acid production, possibly worsening sepsis-related consumption of endogenous antioxidants, a hallmark of septic multi-organ damage [61]. Moreover, its antioxidant activity is manifested through the prevention of lipid peroxidation and oleic acid oxidation. Therefore, in De Andrade and colleagues' murine model, thiamine deficiency was associated with oxidative stress and a proinflammatory state [62]. The clinical consequence is, however, unclear: in a 
large randomized clinical study, the administration of thiamine in ICU patients considered to be thiamine deficient did not improve mortality or ICU stay, but was associated with a lower rate in progression to renal replacement therapy $[63,64]$. In a small observational study, Marik et al. suggested that the combination of hydrocortisone $(50 \mathrm{mg}$ every $6 \mathrm{~h}$ for 4 days), vitamin C (1.5 mg every $6 \mathrm{~h}$ for 4 days), and thiamine (200 mg every $12 \mathrm{~h}$ for 4 days) significantly improved outcomes in patients with sepsis and septic shock [65].

\subsection{Zinc}

Zinc homeostasis may be fundamental in the organism's reaction to sepsis. As an essential trace element, it works as a co-factor for several enzymes and its deficiency leads to delayed wound healing, lymphopenia, and a high incidence of infection [66]. Concentrating on the immune system, zinc is crucial for T-cell maturation and differentiation [67] and protects against the premature apoptosis of immature $\mathrm{T}$ cells, which can lead to altered Th1/Th2 ratios and, eventually, to total T-cell count decrease [68]. On the cellular level, zinc serves as a second messenger and is involved in the development of pro-inflammatory cytokines by monocytes [69] presentation, of major histocompatibility complex type II by dendritic cells [70], and proliferation of T cells [71] via IL-2 stimulation. As part of the acute phase reaction in sepsis, zinc deficiency is linked to an increase in TNF- $\alpha$ and IL- 6 , and to explain this phenomenon, some authors have proposed a model of redistribution of zinc mediated by cytokines [72], and a reduced concentration of serum zinc has been found in septic patients admitted to ICUs for no alimentary reason [73] (Figure 2). A series of studies has found that exposure to LPS and pro-inflammatory cytokines such as IL-6 led to an upregulation of the protein ZIP14 in the liver [74], where it serves as a zinc transporter and is essential for the phosphorylation of c-Met during liver regeneration [75]. In a murine model, ZIP14 ko mice exposed to LPS did not show hypozincemia, but developed hypoglycemia as a mark of hepatic glycemic dysregulation [75]. Where the ZIP14 protein can be upregulated, by contrast, hypozincemia begins within 9 hours [76], and the redistribution of zinc in the liver has been associated with lower degrees of accumulation of superoxide anion and necrotic cell death in the organ [77], suggesting a possible protective role of zinc in acute phase liver dysfunction. On the other hand, a decrease in serum zinc concentration can lead to a downregulation of lymphopoiesis and an upregulation of myelopoiesis, showing a sort of reprogramming of the immune response with a shift from adaptive-based to innately-predominant during hypozincemia [78]. Despite the unclear, but potential, physiological role of zinc redistribution, its serum reduction could lead to higher levels of proinflammatory cytokines, higher oxidative stress, lipid peroxidation, and damage to DNA [79]. Though zinc's role is largely an unexplored path, several studies have shown a correlation between low serum zinc concentration and higher SOFA scores [80], and sepsis non-survivors had much lower zinc concentrations than patients with favorable outcomes [81].

Data regarding a potential beneficial role of zinc supplementation in septic patients still fail to reach statistical significance, though a possible role might be played by albumin, which is the main zinc serum transporter and one of the most important negative acute phase proteins $[82,83]$. For this reason, more evidence is needed to implement zinc administration in standard sepsis treatment and care, even as a possible biomarker in terms of morbidity and outcome.

\section{COVID-19 and Micronutrients: What Is Known}

SARS-CoV-2 infection resulting in COVID-19 has reached an unexpected, worldwide burden in terms of morbidity and mortality, with $5 \%$ of patients hospitalized among all those who tested positive and $20 \%$ of those hospitalized developing a severe illness [84]. The most common clinical presentation includes fever (70-90\%), dry cough (60-86\%), shortness of breath (53-80\%), fatigue (38\%), myalgias (15-44\%), nausea/vomiting or diarrhea (15-39\%), headache, weakness (25\%), and rhinorrhea (7\%). In some cases, anosmia/ageusia can be the presenting symptom $(3 \%)$. Common laboratory findings include lymphopenia 
(83\%), elevated inflammatory markers like erythrocyte sedimentation rate (ESR), C-reactive protein (CRP), ferritin, IL-1, and IL-6. Chest X-rays often reveal bilateral infiltrates with ground glass opacities [85]. A study of 20,133 hospitalized patients in the UK found that $17.1 \%$ had been admitted to high-dependency units or ICUs [86], prompting an exhausting effort by the health system to counteract the pandemic. Impaired function of the heart, brain, liver, lung, kidney, and coagulation systems have been observed, so that approximately 17-35\% of hospitalized patients are currently treated in the ICU, due to hypoxemic respiratory failure in the most common scenario. Interestingly, in the case of COVID-19, the clinical picture of the severe cases requiring ICU admission is characterized by multi-organ failure, with many tracts very similar to those of severe sepsis. Therefore, the mechanisms of disease also seem to have some similarity since in COVID-19 as well in severe sepsis and septic shock, the cause of multi-organ failure is not due to a "cytopathic" effect of the bacteria or the virus, but mainly due to the host's response to the infection.

COVID-19 therapy, especially when treating ICU patients, is strictly supportive, including mechanical ventilation, extracorporeal life support systems such as veno-venous ECMO and antibiotic therapy in the case of bacterial over-infection. Non-specific anti-viral therapy has been proven to be effective in ICU patients. There might be a role, though, for micronutrient supplementation in deficient patients. In the current scenario of limited health resources, it would be important to adopt any adjuvant treatment that may contribute to a better outcome if it is inexpensive and with few or unimportant side effects at tested doses.

\subsection{Vitamin D and COVID-19}

As already described above, vitamin $\mathrm{D}$ as an immunomodulatory agent has a strong rationale also in COVID-19. The risk of developing respiratory tract infections is reduced two-fold in adults with a higher serum concentration of $25(\mathrm{OH}) \mathrm{D}(>38 \mathrm{ng} / \mathrm{mL})[38]$, and the role of $1,25(\mathrm{OH})_{2} \mathrm{D}$ in exerting anti-viral activity and modulating immune response by stimulating cathelicidin release is well known. This leads to the suppression of proinflammatory cytokine release [87]. Furthermore, $1,25(\mathrm{OH})_{2} \mathrm{D}$ specifically acts as a modulator of the renin-angiotensin pathway and is able to downregulate angiotensin-converting enzyme-2 expression, which is known to be the entry receptor for SARS-CoV-2 in cells [88]. Recently, the effect of a single dose of 200,000 IU of vitamin $\mathrm{D}_{3}$ on hospital length of stay in patients with COVID-19 was tested, showing no effect between the vitamin $\mathrm{D}_{3}$ and the placebo group for the primary or secondary end points [89]. This study is paradigmatic of how the basic science should be deeply known to start a clinical trial on the topic to avoid the risk of eventually misleading negative conclusions [90]. In fact, though a loading dose is imperative in acute settings to improve vitamin D levels rapidly, it is unphysiological to give only a loading dose not followed by a maintenance dose [91]. Despite the practical advantage, a single or annual dose has repeatedly been shown to be ineffective or even harmful for respiratory tract infections and musculoskeletal outcomes. Considering the population enrolled in the study, only 115 of 240 patients were vitamin D deficient at baseline ( $25 \mathrm{OHD}<20 \mathrm{ng} / \mathrm{mL}$ ), with no information on the proportion of patients with severe deficiency $(25 \mathrm{OHD}<12 \mathrm{ng} / \mathrm{mL})$. Finally, symptom onset was 10 days before the intervention, so the infection likely took place well over two weeks before the intervention. This topic of the right intervention time returns in many studies approaching micronutrients because it is quite impossible that a single intervention can be the only reason for a change in prognosis when a wide intersection of different pathways has been started with superimposing circles.

\subsection{Vitamin C and COVID-19}

Vitamin C could exert many potentially beneficial roles in counteracting SARS-CoV-2 infection: antiviral, immunomodulatory, anti-inflammatory, and antioxidant effects coexist in molecular pharmacodynamics. In vitro studies have confirmed that vitamin $C$ alone is able to suppress the replication of some viral species, such as herpes simplex-1, influenza 
A, polyvirus type 1 , and rhynovirus [92]. In vivo, vitamin C supplementation can reduce the incidence of postherpetic neuralgi [93] and the duration and severity of the common cold [94]. High-dose vitamin C treatment can also reduce symptoms in patients affected with acquired immune deficiency syndrome (AIDS), being able to ameliorate even the severity of opportunistic infections [95]. Vitamin C is also able to modulate the release of proinflammatory cytokines, and in mice models led to augmented release of interferon, thus being able to reduce lung inflammation in viral pneumonitis [96]. With regard to COVID19 , the combination of vitamin $C$ and quercetin has shown promising synergic antiviral activity [97] and can lead to augmented endothelial repair in widespread microvascular and microvascular thrombosis with increased permeability [98]. In a Chinese trial, high IV dose vitamin C ( $10 \mathrm{~g} /$ day for moderate cases and $20 \mathrm{~g} /$ day for severe cases for 7-10 days) was able to shorten the hospital stay by 3-5 days in 50 patients [99]. In another randomized controlled pilot-trial in three hospitals in China on 56 critically ill COVID-19 patients, $24 \mathrm{~g}$ of vitamin $\mathrm{C}$ was not able to improve the primary outcome (invasive mechanical ventilation-free days in 28 days) and the 28-day mortality ( $p=0.27)$, but it was able to improve the $\mathrm{PaO}_{2} / \mathrm{FiO}_{2}$ ratio in the treatment group on day 7 (229 vs. $151 \mathrm{mmHg}, 95 \% \mathrm{CI}$ $33-122 ; p$ value $=0.01$ ) as well as reduce the value of IL-6 in the treatment group on day 7 $(p=0.04)$ [100]. Both of the reached positive outcomes were clinically relevant and should prompt further investigations on the topic.

\section{Conclusions}

Micronutrients contribute greatly to the human body's homeostasis and metabolism. For decades, they have been considered an ancillary concern in critically ill patients. However, with the current need for a new increase in survival for critically ill patients, they should enter any clinical consideration in daily practice. As another side of the coin, research on this topic should consider not only mortality, since in severely ill patients the outcome is too often confounded by concomitant factors; but reliable and clinically sensitive surrogate outcomes, including the functional recovery of daily activities, should be explored in the coming years.

Author Contributions: Conceptualization, G.M. and K.A.; methodology, M.R. and C.S.; writingoriginal draft preparation, M.R.; writing —-review and editing, G.M., C.S., and K.A. All authors have read and agreed to the published version of the manuscript.

Funding: This research received no external funding.

Institutional Review Board Statement: Not applicable.

Informed Consent Statement: Not applicable.

Data Availability Statement: Not applicable.

Acknowledgments: We acknowledge the contribution of our editor, Warren Blumberg.

Conflicts of Interest: The authors declare no conflict of interest.

\section{References}

1. Adrie, C.; Alberti, C.; Chaix-Couturier, C.; Azoulay, E.; De Lassence, A.; Cohen, Y.; Meshaka, P.; Cheval, C.; Thuong, M.; Troche, G.; et al. Epidemiology and economic evaluation of severe sepsis in France: Age, severity, infection site, and place of acquisition as determinants of workload and cost. J. Crit. Care 2005, 20, 46-58. [CrossRef] [PubMed]

2. Stoller, J.; Halpin, L.; Weis, M.; Aplin, B.; Qu, W.; Georgescu, C.; Nazzal, M. Epidemiology of severe sepsis: 2008-2012. J. Crit. Care 2016, 31, 58-62. [CrossRef] [PubMed]

3. Angus, D.C.; Linde-Zwible, W.T.; Lidicker, J.; Clermont, G.; Carcillo, J.; Pinsky, M.R. Epidemiology of severe sepsis in the Unites States: Analysis of incidence, outcome, and associated costs of care. Crit. Care Med. 2001, 29, 1303-1310. [CrossRef]

4. Dombrovskiy, V.Y.; Martin, A.A.; Sunderram, J.; Paz, H. Rapid increase in hospitalization and mortality rates for severe sepsis in the United States: A trend analysis from 1993 to 2003. Crit. Care Med. 2007, 35, 1244-1250. [CrossRef]

5. Epstein, L.; Dantes, R.; Magill, S.; Fiore, A. Varying estimates of sepsis mortality using death certificates and administrative codes-Unites States, 1999-2014. MMWR Morb. Mortal. Wkly. Rep. 2016, 65, 342-345. [CrossRef] 
6. Belsky, J.B.; Wira, C.R.; Jacob, V.; Sather, J.E.; Lee, P.J. A review of micronutrients in sepsis: The role of thiamine, l-carnitine, vitamin C, selenium and vitamin D. Nutr. Res. Rev. 2018, 31, 281-290. [CrossRef]

7. Martucci, G.; Tuzzolino, F.; Arcadipane, A.; Pieber, T.R.; Schnedl, C.; Urbanic Purkart, T.; Treiber, G.; Amrein, K. The effect of high-dose cholecalciferol on bioavailable vitamin D levels in critically ill patients: A post hoc analysis of the VITdAL-ICU trial. Intensive Care Med. 2017, 43, 1732-1734. [CrossRef]

8. L'Her, E.; Sebert, P. A global approach to energy metabolism in an experimental model of sepsis. Am. J. Respir. Crit. Care Med. 2001, 164, 1444-1447. [CrossRef]

9. Amrein, K.; Oudemans-van Straaten, H.M.; Berger, M.M. Vitamin therapy in critically ill patients: Focus on thiamine, vitamin C, and vitamin D. Intensive Care Med. 2018, 44, 1940-1944. [CrossRef]

10. Prietl, B.; Treiber, G.; Pieber, T.R.; Amrein, K. Vitamin D and immune function. Nutrients 2013, 5, 2502-2521. [CrossRef]

11. Martucci, G.; Volpes, R.; Panarello, G.; Tuzzolino, F.; Di Carlo, D.; Ricotta, C.; Gruttadauria, S.; Conaldi, P.G.; Luca, A.; Amrein, K.; et al. Vitamin D levels in liver transplantation recipients and early postoperative outcomes: Prospective observational DLiverX study. Clin. Nutr. 2020, 40, 2355-2363. [CrossRef]

12. Charoenngam, N.; Shirvani, A.; Holick, M.F. Vitamin D for skeletal and non-skeletal health: What we should know. J. Clin. Orthop. Trauma 2019, 10, 1082-1093. [CrossRef]

13. Haussler, M.R.; Haussler, C.A.; Jurutka, P.W.; Thompson, P.D.; Hsieh, J.C.; Remus, L.S.; Selznick, S.H.; Whitfield, G.K. The vitamin D hormone and its nuclear receptor: Molecular actions and disease states. J. Endocrinol. 1997, 154, S57-S73.

14. Amrein, K.; Scherkl, M.; Hoffmann, M.; Neuwersch-Sommeregger, S.; Köstenberger, M.; Tmava Berisha, A.; Martucci, G.; Pilz, S.; Malle, O. Vitamin D deficiency 2.0: An update on the current status worldwide. Eur J Clin Nutr. 2020, 74, 1498-1513. [CrossRef]

15. Holick, M.F.; Binkley, N.C.; Bischoff-Ferrari, H.A.; Gordon, C.M.; Hanley, D.A.; Heaney, R.P.; Murad, M.H.; Weaver, C.M.; Endocrine, S. Evaluation, treatment, and prevention ofvitamin D deficiency: An Endocrine Society clinical practice guideline. J. Clin. Endocrinol. Metab. 2011, 96, 1911-1930. [CrossRef]

16. Herr, C.; Greulich, T.; Koczulla, R.A.; Meyer, S.; Zakharkina, T.; Branscheidt, M.; Eschmann, R.; Bals, R. The role of vitamin D in pulmonary disease: COPD, asthma, infection, and cancer. Respir. Res. 2011, 12, 31. [CrossRef]

17. Horiuchi, H.; Nagata, I.; Komoriya, K. Protective effect of vitamin D3 analogues on endotoxin shock in mice. Agents Actions 1991, 33, 343-348. [CrossRef]

18. Papapoulos, S.E.; Clemens, T.L.; Fraher, L.J.; Lewin, I.G.; Sandler, L.M.; O'Riordan, J.L. 1, 25-dihydroxycholecalciferol in the pathogenesis of the hypercalcaemia of sarcoidosis. Lancet 1979, 1, 627-630. [CrossRef]

19. Adorini, L.; Penna, G. Induction of tolerogenic dendritic cells by vitamin D receptor agonists. Handb. Exp. Pharmacol. 2009, 188, 251-273.

20. Urry, Z.; Xystrakis, E.; Richards, D.F.; McDonald, J.; Sattar, Z.; Cousins, D.J.; Corrigan, C.J.; Hickman, E.; Brown, Z.; Hawrylowicz, C.M. Ligation of TLR9 induced on human IL-10-secreting Tregs by 1alpha,25-dihydroxyvitamin D3 abrogates regulatory function. J. Clin. Investig. 2009, 119, 387-398.

21. Andrukhova, O.; Slavic, S.; Zeitz, U.; Riesen, S.C.; Heppelmann, M.S.; Ambrisko, T.D.; Markovic, M.; Kuebler, W.M.; Erben, R.G. Vitamin D is a regulator of endothelial nitric oxide synthase and arterial stiffness in mice. Mol. Endocrinol. 2014, $28,53-64$. [CrossRef]

22. Kowalewski, M.; Fina, D.; Słomka, A.; Raffa, G.M.; Martucci, G.; Lo Coco, V.; De Piero, M.E.; Ranucci, M.; Suwalski, P.; Lorusso, R. COVID-19 and ECMO: The interplay between coagulation and inflammation-a narrative review. Crit Care 2020, $24,205$. [CrossRef]

23. Molinari, C.; Uberti, F.; Grossini, E.; Vacca, G.; Carda, S.; Invernizzi, M.; Cisari, C. 1 $\alpha$,25-Dihydroxycholecalciferol Induces Nitric Oxide Production in Cultured Endothelial Cells. Cell. Physiol. Biochem. 2011, 27, 661-668. [CrossRef]

24. Lee, C.; Lau, E.; Chusilp, S.; Filler, R.; Li, B.; Zhu, H.; Yamoto, M.; Pierro, A. Protective effects of vitamin D against injury in intestinal epithelium. Pediatr. Surg. Int. 2019, 35, 1395-1401. [CrossRef]

25. Cantorna, M.T.; Snyder, L.; Lin, Y.D.; Yang, L. Vitamin D and 1,25(OH)2D regulation of T cells. Nutrients 2015, 7, 3011-3021. [CrossRef]

26. Mocanu, V.; Oboroceanu, T.; Zugun-Eloae, F. Current status in vitamin D and regulatory T cells-immunological implications. Med. Surg. J. 2013, 117, 965-973.

27. Mao, X.; Hu, B.; Zhou, Z.; Xing, X.; Wu, Y.; Gao, J.; He, Y.; Hu, Y.; Cheng, Q.; Gong, Q. Vitamin D levels correlate with lymphocyte subsets in elderly patients with age-related diseases. Sci. Rep. 2018, 8, 7708. [CrossRef]

28. Eckard, A.R.; O’Riordan, M.A.; Rosebush, J.C.; Lee, S.T.; Habib, J.G.; Ruff, J.H.; Labbato, D.; Daniels, J.E.; Uribe-Leitz, M.; Tangpricha, V.; et al. Vitamin D supplementation decreases immune activation and exhaustion in HIV-1-infected youth. Antivir. Ther. 2018, 23, 315-324. [CrossRef]

29. Stallings, V.A.; Schall, J.I.; Hediger, M.L.; Zemel, B.S.; Tuluc, F.; Dougherty, K.A.; Samuel, J.L.; Rutstein, R.M. High-dose vitamin D3 supplementation in children and young adults with HIV: A randomized, placebo-controlled trial. Pediatr. Infect. Dis. J. 2015, 34, e32-e40. [CrossRef]

30. Moromizato, T.; Litonjua, A.A.; Braun, A.B.; Gibbons, F.K.; Giovannucci, E.; Christopher, K.B. Association of low serum 25-hydroxyvitamin D levels and sepsis in the critically ill. Crit Care Med. 2014, 42, 97-107. [CrossRef]

31. Lemire, J.M.; Archer, D.C.; Beck, L.; Spiegelberg, H.L. Immunosuppressive actions of 1,25-dihydroxyvitamin D3: Preferential inhibition of Th1 functions. J. Nutr. 1995, 125, 1704S-1708S. 
32. Boonstra, A.; Barrat, F.J.; Crain, C.; Heath, V.L.; Savelkoul, H.F.J.; O'Garra, A. 1 1 ,25-Dihydroxyvitamin D3 Has a Direct Effect on Naive CD4+ T Cells to Enhance the Development of Th2 Cells. J. Immunol. 2001, 167, 4974. [CrossRef]

33. Tang, J.; Zhou, R.; Luger, D.; Zhu, W.; Silver, P.B.; Grajewski, R.S.; Su, S.B.; Chan, C.C.; Adorini, L.; Caspi, R.R. Calcitriol suppresses antiretinal autoimmunity through inhibitory effects on the Th17 effector response. J. Immunol. 2009, 182, 4624-4632. [CrossRef] [PubMed]

34. Rübsamen, D.; Kunze, M.M.; Buderus, V.; Brauß, T.F.; Bajer, M.M.; Brüne, B.; Schmid, T. Inflammatory conditions induce IRES-dependent translation of cyp24a1. PLoS ONE 2014, 9, e85314. [CrossRef]

35. Youssef, D.A.; Miller, C.W.; El-Abbassi, A.M.; Cutchins, D.C.; Cutchins, C.; Grant, W.B.; Peiris, A.N. Antimicrobial implications of vitamin D. Dermato-endocrinology 2011, 3, 220-229. [CrossRef] [PubMed]

36. Khoo, A.L.; Chai, L.Y.; Koenen, H.J.; Kullberg, B.J.; Joosten, I.; van der Ven, A.J.; Netea, M.G. 1,25-dihydroxyvitamin D3 modulates cytokine production induced by Candida albicans: Impact of seasonal variation of immune responses. J. Infect. Dis. 2011, 203, 122-130. [CrossRef] [PubMed]

37. Ginde, A.A.; Mansbach, J.M.; Camargo, C.A., Jr. Association between serum 25-hydroxyvitamin D level and upper respiratory tract infection in the Third National Health and Nutrition Examination Survey. Arch. Intern. Med. 2009, 169, 384-390. [CrossRef]

38. Martineau, A.R.; Jolliffe, D.A.; Hooper, R.L.; Greenberg, L.; Aloia, J.F.; Bergman, P.; Dubnov-Raz, G.; Esposito, S.; Ganmaa, D.; Ginde, A.A.; et al. Vitamin D supplementation to prevent acute respiratory tract infections: Systematic review and meta-analysis of individual participant data. BMJ 2017, 356, i6583. [CrossRef]

39. Amrein, K.; Zajic, P.; Schnedl, C.; Waltensdorfer, A.; Fruhwald, S.; Holl, A.; Purkart, T.; Wünsch, G.; Valentin, T.; Grisold, A.; et al. Vitamin D status and its association with season, hospital and sepsis mortality in critical illness. Crit. Care 2014, 18, R47. [CrossRef]

40. Lucidarme, O.; Messai, E.; Mazzoni, T.; Arcade, M.; du Cheyron, D. Incidence and risk factors of vitamin D deficiency in critically ill patients: Results from a prospective observational study. Intensive Care Med 2010, 36, 1609-1611. [CrossRef]

41. Venkatram, S.; Chilimuri, S.; Adrish, M.; Salako, A.; Patel, M.; Diaz-Fuentes, G. Vitamin D deficiency is associated with mortality in the medical intensive care unit. Crit Care 2011, 15, R292. [CrossRef] [PubMed]

42. Jeng, L.; Yamshchikov, A.V.; Judd, S.E.; Blumberg, H.M.; Martin, G.S.; Ziegler, T.R.; Tangpricha, V. Alterations in vitamin D status and anti-microbial peptide levels in patients in the intensive care unit with sepsis. J. Transl. Med. 2009, 7, 28. [CrossRef]

43. Hulse, J.D.; Ellis, S.; Henderson, L.M. Carnitine biosynthesis: $\beta$ hydroxylation of trimethyllysine by an $\alpha$-keto glutarate dependent mitochondrial dioxygenase. J. Biol. Chem. 1978, 253, 1654-1659. [CrossRef]

44. Harrison, F.; May, J. Vitamin C function in the brain: Vital role of the ascorbate transporter (SVCT2). Free Radic. Biol. Med. 2009, 46, 719-730. [CrossRef] [PubMed]

45. Mandl, J.; Szarka, A.; Banhegyi, G. Vitamin C: Update on physiology and pharmacology. Br. J. Pharmacol. 2009, 157, 1097-1110. [CrossRef] [PubMed]

46. Carr, A.; Maggini, S. Vitamin C and immune function. Nutrients 2017, 9, 1211. [CrossRef] [PubMed]

47. European Food Safety Authority Panel on Dietetic Products, Nutrition and Allergies. Scientific opinion on dietary reference values for vitamin C. EFSA J. 2013, 11, 3418.

48. Fisher, B.J.; Seropian, I.M.; Kraskauskas, D.; Thakkar, J.N.; Voelkel, N.F.; Fowler, A.A.; Natarajan, R. Ascorbic acid attenuates lipopolysaccharide-induced acute lung injury. Crit Care Med 2011, 39, 1454-1460. [CrossRef] [PubMed]

49. Secor, D.; Swarbreck, S.; Ellis, C.G.; Sharpe, M.D.; Tyml, K. Ascorbate reduces mouse platelet aggregation and surface P-selectin expression in an ex vivo model of sepsis. Microcirculation 2013, 20, 502-510. [CrossRef]

50. Carr, A.C.; Shaw, G.M.; Natarajan, R. Ascorbate-dependent vasopressor synthesis: A rationale for vitamin C administration in severe sepsis and septic shock? Crit. Care 2015, 19, 1-8. [CrossRef]

51. Seno, T.; Inoue, N.; Matsui, K.; Ejiri, J.; Hirata, K.I.; Kawashima, S.; Yokoyama, M. Functional expression of sodium-dependent vitamin C transporter 2 in human endothelial cells. J. Vasc. Res. 2004, 41, 345-351. [CrossRef]

52. Khalili, H.; Zabet, M.H.; Mohammadi, M.; Ramezani, M. Effect of high-dose ascorbic acid on vasopressor requirement in septic shock. J. Res. Pharm. Pract. 2016, 5, 94-100. [CrossRef]

53. Fowler, A.A.; Nursing, M.R.I.C.U.; Syed, A.A.; Knowlson, S.; Sculthorpe, R.; Farthing, D.; Dewilde, C.; A Farthing, C.; Larus, T.L.; Martin, E.; et al. Phase I safety trial of intravenous ascorbic acid in patients with severe sepsis. J. Transl. Med. 2014, 12, 32. [CrossRef] [PubMed]

54. Zhang, M.; Jativa, D.F. Vitamin C supplementation in the critically ill: A systematic review and meta-analysis. SAGE Open Med. 2018, 6, 2050312118807615. [CrossRef] [PubMed]

55. Fowler, A.A., 3rd; Truwit, J.D.; Hite, R.D.; Morris, P.E.; DeWilde, C.; Priday, A.; Fisher, B.; Thacker, L.R., 2nd; Natarajan, R.; Brophy, D.F.; et al. Effect of Vitamin C Infusion on Organ Failure and Biomarkers of Inflammation and Vascular Injury in Patients with Sepsis and Severe Acute Respiratory Failure: The CITRIS-ALI Randomized Clinical Trial. JAMA 2019, 322, 1261-1270. [CrossRef]

56. Manzanares, W.; Hardy, G. Thiamine supplementation in the critically ill. Curr. Opin. Clin. Nutr. Metab. Care 2011, 14, 610-617. [CrossRef] [PubMed]

57. Ariaey-Nejad, M.R.; Balaghi, M.; Baker, E.M.; Sauberlich, H.E. Thiamin metabolism in man. Am. J. Clin. Nutr. 1970, 23, 764-778. [CrossRef]

58. DiNicolantonio, J.J.; Niazi, A.K.; Lavie, C.J.; O’Keefe, J.H.; Ventura, H.O. Thiamine supplementation for the treatment of heart failure: A review of the literature. Congest Heart Fail 2013, 19, 214-222. [CrossRef] 
59. Donnino, M.W.; Carney, E.; Cocchi, M.N.; Barbash, I.; Chase, M.; Joyce, N.; Chou, P.P.; Ngo, L. Thiamine deficiency in critically ill patients with sepsis. J. Crit. Care 2010, 25, 576-581. [CrossRef]

60. Costa, N.A.; Gut, A.L.; de Souza Dorna, M.; Pimentel, J.A.C.; Cozzolino, S.M.F.; Azevedo, P.S.; Henrique Fernandes, A.A.; Mamede Zornoff, L.A.; Ruppde Paiva, S.A.; Minicucci, M.F.; et al. Serum thiamine concentration and oxidative stress as predictors of mortality in patients with septic shock. J. Crit. Care 2014, 29, 249-252. [CrossRef]

61. Goode, H.F.; Cowley, H.C.; Walker, B.E.; Howdle, P.D.; Webster, N.R. Decreased antioxidant status and increased lipid peroxidation in patients with septic shock and secondary organ dysfunction. Crit. Care Med. 1995, 23, 646-651. [CrossRef]

62. De Andrade, J.A.A.; Gayer, C.R.M.; Nogueira, N.P.D.A.; Paes, M.C.; Bastos, V.L.F.C.; Neto, J.D.C.B.; Alves, S.C.; Coelho, R.M.; Da Cunha, M.G.A.T.; Gomes, R.N.; et al. The effect of thiamine deficiency on inflammation, oxidative stress and cellular migration in an experimental model of sepsis. J. Inflamm. 2014, 11, 11. [CrossRef]

63. Donnino, M.W.; Andersen, L.W.; Chase, M.; Berg, K.M.; Tidswell, M.; Giberson, T.; Wolfe, R.; Moskowitz, A.; Smithline, H.; Ngo, L.; et al. Randomized, double-blind, placebo-controlled trial of thiamine as a metabolic resuscitator in septic shock: A pilot study. Crit. Care Med. 2016, 44, 360-367. [CrossRef] [PubMed]

64. Moskowitz, A.; Andersen, L.W.; Cocchi, M.N.; Karlsson, M.; Patel, P.V.; Donnino, M.W. Thiamine as a renal protective agent in septic shock: A secondary analysis of a randomized, double-blind, placebo-controlled trial. Ann. Am. Thorac. Soc. 2017, 14, 737-741. [CrossRef] [PubMed]

65. Marik, P.E.; Khangoora, V.; Rivera, R.; Hooper, M.H.; Catravas, J. Hydrocortisone, vitamin C and thiamine for the treatment of severe sepsis and septic shock: A retrospective before-after study. Chest 2016, 151, 1229-1238. [CrossRef] [PubMed]

66. King, L.E.; Frentzel, J.W.; Mann, J.J.; Fraker, P.J. Chronic zinc deficiency in mice disrupted T cell lymphopoiesis and erythropoiesis while B cell lymphopoiesis and myelopoiesis were maintained. J. Am. Coll. Nutr. 2005, 24, 494-502. [CrossRef] [PubMed]

67. Incefy, G.S.; Mertelsmann, R.; Yata, K.; Dardenne, M.; Bach, J.F.; Good, R.A. Induction of differentiation in human marrow T cell precursors by the synthetic serum thymic factor, FTS. Clin. Exp. Immunol. 1980, 40, 396-406.

68. Prasad, A.S. Effects of zinc deficiency on Th1 and Th2 cytokine shifts. J. Infect. Dis. 2000, 182, S62-S68. [CrossRef] [PubMed]

69. Haase, H.; Ober-Blöbaum, J.L.; Engelhardt, G.; Hebel, S.; Heit, A.; Heine, H.; Rink, L. Zinc signals are essential for lipopolysaccharide-induced signal transduction in monocytes. J. Immunol. 2008, 181, 6491-6502. [CrossRef]

70. Kitamura, H.; Morikawa, H.; Kamon, H.; Iguchi, M.; Hojyo, S.; Fukada, T.; Yamashita, S.; Kaisho, T.; Akira, S.; Murakami, M.; et al. Toll-like receptor-mediated regulation of zinc homeostasis influences dendritic cell function. Nat. Immunol. 2006, 7, 971. [CrossRef]

71. Kaltenberg, J.; Plum, L.M.; Ober-Blöbaum, J.L.; Hönscheid, A.; Rink, L.; Haase, H. Zinc signals promote IL-2-dependent proliferation of T cells. Eur. J. Immunol. 2010, 40, 1496-1503. [CrossRef]

72. Gaetke, L.M.; McClain, C.J.; Talwalkar, R.T.; Shedlofsky, S.I. Effects of endotoxin on zinc metabolism in human volunteers. Am. J. Physiol. Endocrinol. Metab. 1997, 272, E952-E956. [CrossRef]

73. Besecker, B.Y.; Exline, M.C.; Hollyfield, J.; Phillips, G.; DiSilvestro, R.A.; Wewers, M.D.; Knoell, D.L. A comparison of zinc metabolism, inflammation, and disease severity in critically ill infected and noninfected adults early after intensive care unit admission123. Am. J. Clin. Nutr. 2011, 93, 1356-1364. [CrossRef] [PubMed]

74. Huber, K.L.; Cousins, R.J. Metallothionein expression in rat bone marrow is dependent on dietary zinc but not dependent on interleukin-1 or interleukin-6. J. Nutr. 1993, 123, 642-648. [CrossRef] [PubMed]

75. Aydemir, T.B.; Chang, S.M.; Guthrie, G.J.; Maki, A.B.; Ryu, M.S.; Karabiyik, A.; Cousins, R.J. Zinc transporter ZIP14 functions in hepatic zinc, iron and glucose homeostasis during the innate immune response (endotoxemia). PLoS ONE 2012,7 , e48679.

76. Wessels, I.; Cousins, R.J. Zinc dyshomeostasis during polymicrobial sepsis in mice involves zinc transporter Zip14 and can be overcome by zinc supplementation. Am. J. Physiol. Gastrointest. Liver Physiol. 2015, 309, G768-G778. [CrossRef] [PubMed]

77. Zhou, Z.; Wang, L.; Song, Z.; Saari, J.T.; McClain, C.J.; Kang, Y.J. Abrogation of nuclear factor-kB activation is involved in zinc inhibition of lipopolysaccharide-induced tumor necrosis factor- $\alpha$ production and liver injury. Am. J. Pathol. 2004, 164, 1547-1556. [CrossRef]

78. Fraker, P.J.; King, L.E. Reprogramming of the immune system during zinc deficiency. Annu. Rev. Nutr. 2004, 24, 277-298. [CrossRef]

79. Song, Y.; Chung, C.S.; Bruno, R.S.; Traber, M.G.; Brown, K.H.; King, J.C.; Ho, E. Dietary zinc restriction and repletion affects DNA integrity in healthy men. Am. J. Clin. Nutr. 2009, 90, 321-328. [CrossRef]

80. Cander, B.; Dundar, Z.D.; Gul, M.; Girisgin, S. Prognostic value of serum zinc levels in critically ill patients. J. Crit. Care 2011, 26, 42-46. [CrossRef]

81. Hoeger, J.; Simon, T.-P.; Beeker, T.; Marx, G.; Haase, H.; Schuerholz, T. Persistent low serum zinc is associated with recurrent sepsis in critically ill patients-A pilot study. PLoS ONE 2017, 12, e0176069. [CrossRef]

82. Foote, J.W.; Delves, H.T. Albumin bound and alpha 2-macroglobulin bound zinc concentrations in the sera of healthy adults. J. Clin. Pathol. 1984, 37, 1050-1054. [CrossRef]

83. Castell, J.V.; Gömez-Lechön, M.J.; David, M.; Andus, T.; Geiger, T.; Trullenque, R.; Fabra, R.; Heinrich, P.C. Interleukin-6 is the major regulator of acute phase protein synthesis in adult human hepatocytes. FEBS Lett. 1989, 242, 237-239. [CrossRef]

84. Wiersinga, W.J.; Rhodes, A.; Cheng, A.C.; Peacock, S.J.; Prescott, H.C. Pathophysiology, Transmission, Diagnosis, and Treatment of Coronavirus Disease 2019 (COVID-19): A Review. JAMA 2020, 324, 782-793. [CrossRef] 
85. Xu, Z.; Shi, L.; Wang, Y.; Zhang, J.; Huang, L.; Zhang, C.; Liu, S.; Zhao, P.; Liu, H.; Zhu, L.; et al. Pathologicalfindings of COVID-19 associated with acute respiratory distress syndrome. Lancet Respir. Med. 2020, 8, 420-422. [CrossRef]

86. Docherty, A.B.; Harrison, E.M.; Green, C.A.; Hardwick, H.E.; Pius, R.; Norman, L.; Holden, K.A.; Read, J.M.; Donderlinger, F.; Carson, G.; et al. ISARIC4C investigators. Features of 20133 UK patients in hospital with COVID-19 using the ISARIC WHO Clinical Characterisation Protocol: Prospective observational cohortstudy. BMJ 2020, 369, m1985. [CrossRef] [PubMed]

87. Matthay, M.A.; Zemans, R.L. The acute respiratory distress syndrome: Pathogenesis and treatment. Annu. Rev. Pathol. 2011, 6, 147-163. [CrossRef] [PubMed]

88. Cui, C.; Xu, P.; Li, G.; Qiao, Y.; Han, W.; Geng, C.; Liao, D.; Yang, M.; Chen, D.; Jiang, P. Vitamin Dreceptor activation regulates microglia polarization and oxidative stress in spontaneously hypertensive rats and angiotensin II-exposed microglial cells: Role of renin-angiotensin system. Redox Biol. 2019, 26, 101295. [CrossRef] [PubMed]

89. Murai, I.H.; Fernandes, A.L.; Sales, L.P.; Pinto, A.J.; Goessler, K.F.; Duran, C.S.C.; Silva, C.B.R.; Franco, A.S.; Macedo, M.B.; Dalmolin, H.H.H.; et al. Effect of a single dose of vitamin D on hospital length of stay in patients with moderate to severe COVID-19. JAMA 2021, Online ahead of print. [CrossRef]

90. Rubin, R. Sorting out whether vitamin D deficiency raises COVID-19 risk. JAMA 2021, 325, 329-330. [CrossRef] [PubMed]

91. Amrein, K.; Parekh, D.; Westphal, S.; Preiser, J.-C.; Berghold, A.; Riedl, R.; Eller, P.; Schellongowski, P.; Thickett, D.; Meybohm, P. Effect of high-dose vitamin D3 on 28-day mortality in adult critically ill patients with severe vitamin D deficiency: A study protocol of a multicentre, placebo-controlled double-blind phase III RCT (the VITDALIZE study). BMJ Open 2019, 9, e031083. [CrossRef]

92. Furuya, A.; Uozaki, M.; Yamasaki, H.; Arakawa, T.; Arita, M.; Koyama, A. Antiviral effects of ascorbic and dehydroascorbic acids in vitro. Int J Mol Med. 1998, 22, 541-545.

93. Chen, J.; Chang, C.; Feng, P.; Chu, C.; So, E.; Hu, M. Plasma vitamin C is lower in postherpetic neuralgia patients and administration of vitamin $C$ reduces spontaneous pain but not brush-evoked pain. Clin. J. Pain 2009, 25, 562-569. [CrossRef] [PubMed]

94. Hemilä, H.; Chalker, E. Vitamin C for preventing and treating the common cold. Cochrane Database Syst. Rev. 2013. [CrossRef] [PubMed]

95. Cathcart, R. Vitamin C in the treatment of acquired immune deficiency syndrome (AIDS). Med. Hypotheses 1984, 14, 423-433. [CrossRef]

96. Kim, H.; Jang, M.; Kim, Y.; Choi, J.; Jeon, J.; Kim, J.; Hwang, Y.; Kang, J.S.; Lee, W.J. Red ginseng and vitamin C increase immune cell activity and decrease lung inflammation induced by influenza A virus/H1N1 infection. J. Pharm. Pharmacol. 2016, 68, 406-420. [CrossRef]

97. Colunga Biancatelli, R.; Berrill, M.; Catravas, J.; Marik, P. Quercetin and vitamin C: An experimental, synergistic therapy for the prevention and treatment of SARS-CoV-2 related disease (COVID-19). Front. Immunol. 2020. [CrossRef] [PubMed]

98. Pons, S.; Fodil, S.; Azoulay, E.; Zafrani, L. The vascular endothe- lium: The cornerstone of organ dysfunction in severe SARSCoV-2 infection. Crit. Care 2020. [CrossRef]

99. Zhang, J.; Rao, X.; Li, Y.; Zhu, Y.; Liu, F.; Guo, G.; Luo, G.; Meng, Z.; De Backer, D.; Xiang, H.; et al. Pilot trial of high-dose vitamin $\mathrm{C}$ in critically ill COVID-19 patients. Ann. Intensive Care 2021, 11, 5. [CrossRef]

100. Bilezikian, J.P.; Bikle, D.; Hewison, M.; Lazaretti-Castro, M.; Formenti, A.M.; Gupta, A.; Madhavan, M.V.; Nair, N.; Babalyan, V.; Hutchings, N.; et al. Mechanisms in endocrinology: Vitamin D and COVID-19. Eur. J. Endocrinol. 2020, 183, R133-R147. [CrossRef] 